\title{
Actinic keratosis of the lower lip treated with photodynamic therapy
}

\author{
Meng Zhang MD, Hao Guo MD, Jiu-Hong Li MD PhD
}

Cite as: CMAJ 2021 June 14;193:E912. doi: 10.1503/cmaj.202674

A 57-year-old man who was otherwise healthy presented to our dermatology clinic with a 6-month history of a painful mass on his lower lip. He worked outdoors with substantial lifelong sun exposure and he had a 20 pack-year smoking history. The lesions on his lip started as erythematous papules that had repeatedly ulcerated and slowly expanded. Physical examination showed a well circumscribed region of white hyperplasia, papillomatous hyperplasia and keratosis of his lower lip (Figure 1A). The rest of the physical examination was normal, including inspection of the cervical lymph nodes. Laboratory test results, including serology for syphilis and HIV antibodies, were unremarkable. Histopathologic biopsy at the junction of white hyperplasia and papillomatous hyperplasia confirmed a diagnosis of actinic keratosis (Appendix 1, available at www.cmaj.ca/lookup/ doi/10.1503/cmaj.202674/tab-related-content). Three weeks of topical imiquimod (5\%) had been previously attempted without any effect, and the patient was reluctant to have a surgical excision, so we proceeded with 5 weekly sessions of photodynamic therapy (PDT) using topical 5-aminolevulinic acid (ALA) as a photosensitizing agent. We applied 20\% ALA (118 mg) to the lesions with covering dressings for 3 hours, then treated with $632 \mathrm{~nm}$ noncoherent red light of $90 \mathrm{~mW} / \mathrm{cm}^{2}$ for 30 minutes. At a 3-month followup visit, we observed a remarkable cosmetic effect (Figure 1B).

Actinic keratoses are precancerous lesions, with about $10 \%$ progressing into invasive squamous cell carcinomas. ${ }^{1}$ They frequently arise on sun-exposed areas (e.g., face, scalp, neck, hands and forearms). ${ }^{2}$ The differential diagnosis includes lichen planus, squamous cell carcinoma, cutaneous horn and keratoacanthoma. These can be distinguished readily with biopsy examination. Effective therapeutic options include cryotherapy, laser therapy, surgery, curettage, PDT and topical therapy with 5-fluorouracil, diclofenac $3 \%$ gel, or imiquimod. 2,3 We suggested PDT for this patient based on the site of the lesions, the failure to respond to topical medication and the patient's preference for nonsurgical interventions. ${ }^{3,4}$ In addition, we suggested smoking cessation, given the probable contribution of tobacco to lesion development and recurrence. ${ }^{1} \mathrm{He}$ will be followed every 3 months, as the risk of recurrence within 12 months is $22 \%{ }^{4}$

\section{References}

1. Jadotte YT, Schwartz RA. Solar cheilosis: an ominous precursor: part I. Diagnostic insights. J Am Acad Dermatol 2012;66:173-84.

2. Dianzani C, Conforti C, Giuffrida R, et al. Current therapies for actinic keratosis. Int J Dermatol 2020;59:677-84.

3. Piquero Casals J, Morgado CD, Gilaberte Y, et al. Management pearls on the treatment of actinic keratoses and field cancerization. Dermatol Ther (Heidelb) 2020;10:903-15.

4. Morton CA, Szeimies RM, Basset SN, et al. European Dermatology Forum guidelines on topical photodynamic therapy 2019 Part 1: treatment delivery and established indications - actinic keratoses, Bowen's disease and basal cell carcinomas. J Eur Acad Dermatol Venereol 2019;33:2225-38.

\section{Competing interests: None declared.}

This article has been peer reviewed.

The authors have obtained patient consent.

Affiliation: Department of Dermatology, the First Hospital of China Medical University, Shenyang, China

Funding: This work was supported by NSFC (81903228 HG).

Content licence: This is an Open Access article distributed in accordance with the terms of the Creative Commons Attribution (CC BY-NCND 4.0) licence, which permits use, distribution and reproduction in any medium, provided that the original publication is properly cited, the use is noncommercial (i.e., research or educational use), and no modifications or adaptations are made. See: https://creativecommons. org/licenses/by-nc-nd/4.0/

Acknowledgements: The authors thank Dr. Song Zheng and Dr. Bo Li for their assistance in pathology.

Correspondence to: Jiu-Hong Li, Pfkl2011@126.com 